\title{
TOTAL GLYCEROL IN THE EXCURRENT DUCTS OF THE MALE RAT
}

\author{
G. D. HODGEN \\ Reproduction Research Branch National Institute of Child Health and \\ Human Development, National Institutes of Health, Bethesda, Maryland 20014, U.S.A.
}

(Received 6th fuly 1971, accepted 1st September 1971)

Some evidence suggests that the male antifertility agent, 3-chloro-1,2-propanediol, may damage the vascular supply of the rat caput epididymidis and interfere with sperm maturation (Gunn, Gould \& Anderson, 1969; Ericsson \& Baker, 1970). Gunn et al. (1969) suggested that this chlorhydrin may act through interference with the secretion or utilization of glycerylphosphorylcholine within the epididymis. This proposal was considered because of the already established importance of glycerylphosphorylcholine within this context (Mann, 1964). However, if 3-chloro-1,2-propanediol were metabolized through pathways in which glycerol was the normal substrate, the first point at which to detect this proposed effect of chlorhydrin treatment would be in the total glycerol pool, itself, rather than by measurements of various phospholipid intermediates along the pathway from free glycerol to lecithin (Kennedy, 1961).

The structural similarity of 3-chloro-1,2-propanediol to the glycerol molecule has led us to investigate the possibility that this chlorhydrin may act as a metabolic analogue of glycerol. This investigation was designed to measure the total glycerol concentrations throughout the excurrent duct system of the normal. adult rat and to determine if 3-chloro-1,2-propanediol treatment alters the total glycerol levels in any of the tissues responsible for sperm production, maturation and transport.

A total of fifteen normal, mature, male Sprague-Dawley rats (350 to $500 \mathrm{~g}$ ) were maintained under standard laboratory nutritional and housing conditions. One group of five animals received no injections and served as basic controls. Five other animals received $0 \cdot 25 \mathrm{ml}$ of subcutaneously injected 3-chloro-1,2propanediol in $0.25 \%$ methylcellulose $(15 \mathrm{mg} / \mathrm{kg}$ intrascapularly) daily for 10 days. The remaining animals were similarly injected with $10 \%$ glycerol instead of the chlorhydrin.

Testes, epididymides (caput, corpus and cauda), ductus deferens and seminal vesicles with coagulating glands were trimmed of fat and connective tissues and weighed individually. Each testis, segment of epididymis and vas deferens tissue was homogenized in distilled water $\left(3^{\circ} \mathrm{C}\right)$ and centrifuged at $600 \mathrm{~g}$ for $20 \mathrm{~min}$. The supernatants were deproteinized using $2 \% \mathrm{ZnSO}_{4}$ and $0 \cdot 1$ $\mathrm{N}-\mathrm{NaOH}$ (White, 1959). Total glycerol concentrations were determined after copper-lime treatment Ryley, 1955; White, 1959).

Results of the total glycerol concentrations in the reproductive tract tissues 
of the control rats are presented in Table 1 . Total glycerol progressively increased from the levels found in the testis homogenates and caput epididymidis to more than six times this value in homogenates of corpus epididymidis. The total glycerol concentration decreased progressively in homogenates of cauda epididymidis and ductus deferens to nearly one-half the peak concentration of the

Table 1

CONCENTRATION OF TOTAL GLYCEROL IN REPRODUCTIVE TRACT TISSUES OF UNINJECTED CONTROL MALE RATS

\begin{tabular}{l|rrr|rrr}
\hline & \multicolumn{3}{|c|}{$\mu g$ glycerollg of wet weight } & \multicolumn{3}{c}{$\mu g$ glycerollg dry weight } \\
\multicolumn{1}{c|}{ Tissue } & Mean* & S.D. & \multicolumn{1}{c|}{ Range } & Mean* & \multicolumn{1}{c}{ S.D. } & \multicolumn{1}{c}{ Range } \\
\hline Testis & 266 & 7 & 252 to 275 & 3094 & 366 & 2771 to 3680 \\
Epididymis & & & & & & \\
$\quad$ Caput & 1000 & 30 & 945 to 1035 & 7438 & 1189 & 5698 to 8637 \\
$\quad$ Corpus & 2499 & 166 & 2280 to 2836 & 17119 & 1340 & 15230 to 18819 \\
$\quad$ Cauda & 1821 & 62 & 1742 to 1905 & 14178 & 566 & 13523 to 14803 \\
Ductus deferens & 1183 & 140 & 839 to 1455 & 9422 & 1799 & 7576 to 11719 \\
\hline
\end{tabular}

$* N=10$.

TABLE 2

GONGENTRATION OF TOTAL GLYGEROL IN REPRODUGTIVE TRACT TISSUES OF MALE RATS AFTER INJECTION OF 3-GHLORO-1,2-PROPANEDIOL OR GLYCEROL

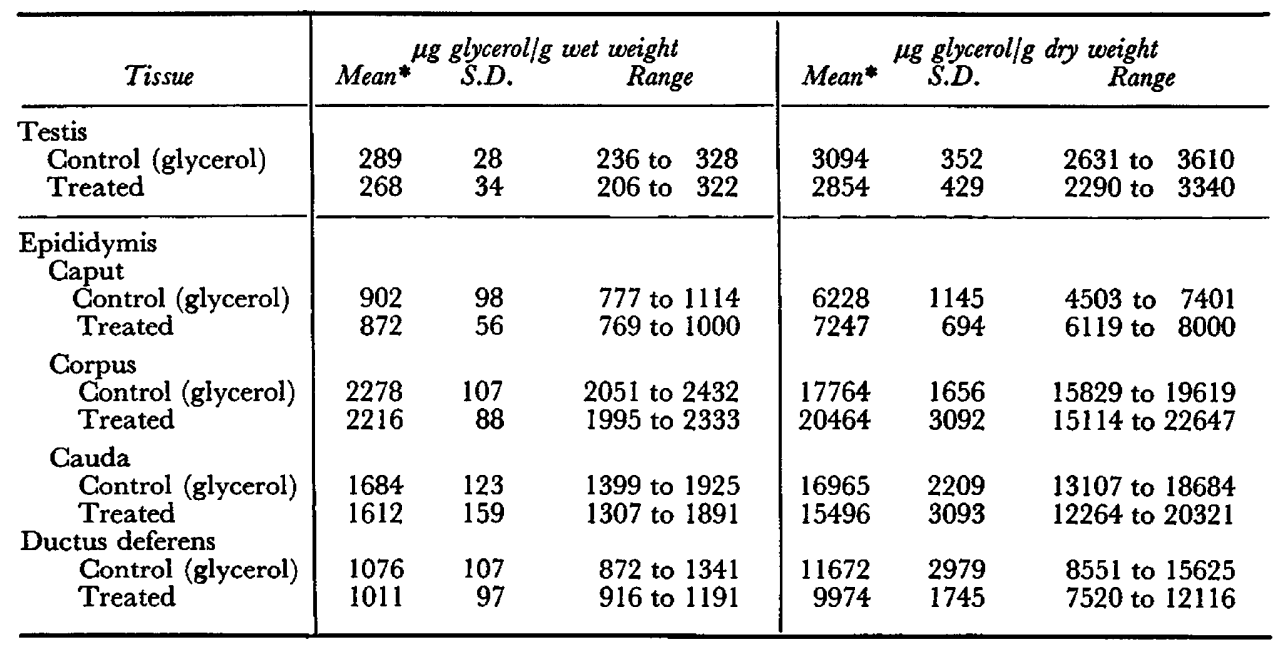

$$
* \mathrm{~N}=10 \text {. }
$$

corpus epididymidis. This characteristic, progressive rise and decline in total glycerol levels along the excurrent duct system is quite similar to that of glycerylphosphorylcholine in rat excurrent duct fluid taken from these same tissues (Mann, 1964).

Table 2 shows the total glycerol levels in the excurrent duct tissues of rats that were injected with either 3-chloro-1,2-propanediol or glycerol. Because the 
chlorhydrin dose employed caused severe oedema of the epididymal tissues, total glycerol concentrations are expressed using both wet and dry tissue weights. The data show that 3-chloro-1,2-propanediol, under the conditions of this investigation, did not change the total glycerol concentrations in any portion of the excurrent duct system examined. By comparing the data in Tables 1 and 2, it is evident that the total glycerol concentration characteristically rose to a peak in the corpus epididymidis and declined in the duct tissues more distal from the testis. This finding was consistent in the control, glycerol-injected, and chlorhydrin-treated groups.

The data in Table 3 demonstrate that the lack of effect of 3-chloro-1,2propanediol to alter total glycerol levels was not due to complete ineffectiveness of the drug. Epididymal oedema was quite evident in the caput epididymidis and to a lesser extent in segments taken from the corpus and cauda epididy-

TABLE 3

EFFECT OF 3-GHLORO-1,2-PROPANEDIOL ON WEIGHTS OF REPRODUCTIVE TRAGT TISSUES IN MALE RATS

\begin{tabular}{|c|c|c|c|}
\hline \multirow[b]{2}{*}{$\begin{array}{c}\text { Organ } \\
\text { (unilateral) }\end{array}$} & \multicolumn{2}{|c|}{ Wet weight $(\mathrm{mg})^{*}$} & \multirow{2}{*}{$\begin{array}{l}\text { Change as \% of } \\
\text { glycerol injected } \\
\text { control }\end{array}$} \\
\hline & $\begin{array}{c}\text { Glycerol } \\
\text { control } \dagger\end{array}$ & Chloro-1, & \\
\hline Testis & 1994 & 1835 & - \\
\hline $\begin{array}{l}\text { Epididymis } \\
\text { caput } \\
\text { corpus } \\
\text { cauda }\end{array}$ & $\begin{array}{r}319 \\
82 \\
293\end{array}$ & $\begin{array}{l}505 \\
103 \\
321\end{array}$ & $\begin{array}{l}158 \cdot 3 \\
125 \cdot 6 \\
109 \cdot 6\end{array}$ \\
\hline Ductus deferens & 55 & 58 & $\omega$ \\
\hline Seminal vesicle & 785 & 862 & - \\
\hline Coagulating gland & 88 & 87 & - \\
\hline
\end{tabular}

* Mean values for $\mathrm{N}=10$.

$\dagger$ Final body wt (Mean \pm S.D. $)=479 \pm 28$.

\pm Final body wt (Mean \pm S.D. $)=472 \pm 16$.

\$ Listed only if statistically significant $(P>0 \cdot 05)$.

midis. This effect of the chlorhydrin was confined to the epididymis and confirmed an earlier report (Gunn et al., 1969). Recently, Turner (1971) has shown that 3-chloro-1,2-propanediol reduced the fertilizing capacity of mature spermatozoa from the ductus deferens even though no oedema was detected in this tissue. The chlorhydrin also altered the blood flow within the epididymis.

These data show that the total glycerol concentrations in the excurrent duct tissues of the adult male rat have a characteristic pattern which subsequent investigations may relate to metabolic events specific to the processes of sperm maturation. The data also suggest that 3-chloro-1,2-propanediol may not act as a metabolic analogue of glycerol.

The author is grateful to Dr William W. Tullner for his suggestions and to $\mathrm{Mr}$ Archibald Jackson for his technical assistance. 


\section{REFERENGES}

ERICsson, R. J. \& BAKer, V. F. (1970) Male antifertility compounds: biological properties of U-5897 and U-15,646. F. Reprod. Fert. 21, 267.

Gunn, S. A., Gould, T. C. \& Anderson, W. A. D. (1969) Possible mechanism of posttesticular antifertility action of 3-chloro-1,2-propanediol. Proc. Soc. exp. Biol. Med. 132, 656.

Kennedy, E. P. (1961) Biosynthesis of complex lipids. Fedn Proc. Fedn Am. Socs exp. Biol. 20, 934.

ManN, T. (1964) The biochemistry of semen and of the male reproductive tract, p. 205. Wiley, New York.

RyLEY, J. F. (1955) Studies on the metabolism of protozoa. Biochem. 7. 59, 353.

TURNER, M. A. (1971) Effects of $\alpha$-chlorhydrin upon the fertility of spermatozoa of the cauda epididymidis of the rat. F. Reprod. Fert. 24, 267.

Whrte, I. G. (1959) Studies on the estimation of glycerol, fructose and lactic acid with particular reference to semen. Aust. F. $\exp$. Biol. 37, 441 . 